\title{
The Principle and Current Situation of the Theory of Administrative Hearing System in Colleges and Universities
}

\author{
Hui-Hua Zhang \\ College of Law, South China University of Technology, Higher Education Mega Center, Guangzhou, 510006, China \\ E-mail: hhzhang1@scut.edu.cn, 553662117@qq.com
}

\begin{abstract}
Hearing right is a product of human development to a certain historical stage, it has a profound social foundation, and the market economy, democratic politics and the rights of culture have inherent correlation. Hearing right of colleges and universities as the other party to participate in the administrative subject in colleges and universities make the procedural rights of administrative act, the right to a hearing of the institutionalization is the procedural guarantee of just exercise the power of colleges and universities, is the effective way to realize the rights of the other party to participate in the administrative, also is more advantageous to realize the administrative department and the other party is better to important legal mechanism of mutual interaction.
\end{abstract}

Keywords- Management of Colleges and Universities; the Hearing System; Principle and Present Situation

\section{INTRODUCTION}

\section{A. The Meaning of the Hearing System in Colleges and Universities Management}

The word "hearing": to should listen to the opinions of the parties on litigation system, it was originally used only for the exercise of jurisdiction, as the judicial activities of the program, called "judicial hearing. [1] The hearing has broad sense and narrow sense. Generalized hearing, generally refers to the state organs before a decision is made to the interested party provides an opportunity to comment, the specific matters the cross-examination, contentious procedure. Narrow sense of hearing, is refers to the administrative departments in order to reasonably and effectively develop and implement administrative decision, publicly held by interested persons to participate in the hearing, extensive listening to the opinions of all aspects of activities, to ensure that the administrative organs of the administrative decision reasonable and lawful. [2] administrative hearing system in colleges and universities is mainly related to the narrow sense of hearing, the major management decisions related to the core rights and interests of staff and students, hearing listen to the views of interested people and the collective, can make the decision to better reflect people's wisdom and advice, to provide a public platform for the public, to better reflect democracy.

Administrative hearing system in colleges and universities refers to the other party to participate in the activities of administrative subject in colleges and universities management services, to protect the justified and lawful rights and interests, the parties for the administrative behavior of colleges and universities, listen to the opinions of the interested party and relating to matters of after the floorboard of the normative procedure system.

\section{THE LEGAL BASIS OF UNIVERSITY ADMINISTRATIVE HEARING SYSTEM}

The principle of "natural justice" and "due process of law" is the source of the basic theories of administrative hearing system in colleges and universities."Natural justice principle" and "due process of law" is the common law countries formed since the modern times, including hearing system, almost all the foundation of the legal system.

Wade pointed out in the "administrative law", "natural justice principle" is the legal basis of the hearing system, the hearing in article 39 of the charter of the free, in fact, is as a clause to be established. [3] The American scholar Bernard Schwartz in American legal history, "a book points out that" due process of law "is the all American constitutional system, including hearing procedure. [4]

Earlier in the law of establishing the system of administrative hearing is the federal administrative procedural law. The regulation of the laws, changed the traditional administrative law on the principle of "administrative efficiency first", and to guarantee citizens' basic rights and control principle of the rule of law of executive power. The parties shall have the right to get the chance of defending their own interests; this right is the rights of the hearing. [5]

"Any rights must be justice; adverse decision must be consulted on the parties." "Natural justice principle including the two most basic procedural rules: one is anyone or groups in the exercise of rights are likely to make other people suffer must listen to the opinions of the other party, everyone for his defense and right to defense. The second is anyone or groups as a judge in his own case." This principle was originally dominated the court activity rules, a program was later year to the administrative procedure, become the dominant and the principle of administrative activities, which is the direct legal basis of modern hearing system. This principle includes three aspects: the content of the citizen has the power to be notified within a reasonable time before; Must have citizens shall have the right to authority decision point and according to the right; Citizens have the right to defend himself. [6] 


\section{THE LEGAL SOURCE OF THE HEARING PROCEDURE IN OUR COUNTRY}

The legal sources of the hearing procedure in our country are: first, the constitution. Constitution prescribed in paragraph 2 of article 27: "all state organs and state functionaries must rely on the support of the people, always keep in close contact with the people, to listen to people's opinions and Suggestions, accept the supervision of the people, to serve the people." Listen to people's opinions and Suggestions in making administrative hearing system in colleges and universities can be refined. Second, the law on administrative punishments : "Legislative law", "administrative licensing law". The eighth National People's Congress four conference on March 17, 1996, examined and approved the law on administrative punishments, and establish the hearing system in the law. On July 1st, 2000, the implementation of the "legislative law" clearly the extension of the hearing in the field of administrative legislation. On August 27th, 2003, passed the "administrative licensing law" provisions of the administrative licensing hearing system in the field of management, further expanded the breadth of the administrative hearing system. Third, the higher education law and education law, including clear rules for student shall have the right to be fair assessment, which is the realization of fair appraisal rights, scenes program is one of the important link. Fourth, 2005 "common colleges and universities student management stipulation", including the second chapter 5 , article 56 to article 64 of the fifth chapter, all to the university education administration for the hearing procedure has made the principle rules. [7]

Our country many government management departments to make the special hearing procedure, rule, or method. Hearing in price decision, local legislation, administrative penalties, state compensation in areas such as widely adopted, this undoubtedly the establishment of the hearing system for colleges and universities management provides the base and can draw lessons from the experience of the legal system.

\section{THE LACK OF THE HEARING STATUS OF COLLEGES AND UNIVERSITIES}

In 2000, a graduate student at east China University of politics and law is going to graduate student grade treatment decision of something, held a hearing; it is the first time in university's internal administrative management in the implementation of the hearing. In 2003, sun yat-sen university first meal price hearings. National ministry of education in 2005 revision of the "common colleges and universities student management stipulation", has been clear about the student to the disciplinary right of appeal, many colleges and universities are in the school the working method of regulation: the appeal of the review process, you can take the hearing manner, and the meeting has made the detailed procedures of hearing. In June 2006, south China normal university for college students who was expelled for cheating in the exam of the hearing, the first time in the Guangdong university student appeal hearing. In 2007,
Zhejiang university and expanded the scope of hearing system to the formulation of regulatory documents, teacher appeal, etc. In recent years, the hearing system in the practice of university administrative management success, larger promote the democratization and legalization of the university management process, is better to protect the legitimate rights and interests of staff and students, is to maintain the expression between teachers and students, the right of participation, right to know, is an effective way of supervision. But in recent years the hearing practice, there are the following:

\section{A. The Hearing Scope is too Narrow}

Implementation of the hearing system in colleges and universities focus on student management level, and other internal management school, such as involving the vital interests of the staff and students decide matters, to teacher's major processing, the administrative personnel appointments, etc, in the hearing of few and far between. Such as adjust the hearing be held in Hainan university tuition fees, to be held in March 2016, Hainan province department of education fair education tuition adjustment hearing ordinary undergraduate course colleges and universities. 10 seats set attend the hearing, the hearing the hearing participants seats 25 , by students or their parents, some universities, relevant experts and scholars, government departments, social organizations and other personnel, consignment xiaomei, vice-governor and made relevant units respectively. Time and place of hearing and tuition adjustment scheme points of hearing, the hearing and the hearing participants list will be announced to the public hearing was 15. [8]

The student management in the field of the set up hearing system, student major disciplinary processes "later". For example, many colleges and universities in recent years in the student disciplinary punishment rules hearing, points to is "involves my rights and interests of the students for the school to make the object to the decision of", put forward the school in accordance with the provisions of the hearing request. From the point of view of the protection of rights, all related to major rights and interests of the parties before the decision is necessary to enable the hearing procedure.

\section{B. The Education Laws and Regulations the Regulations of Administrative Hearing System in Colleges and Universities is Weak}

The present related laws and regulations of higher education in our country the general lack of hearing system is effective right relief mechanism. Even if there are some very limited remedy procedures about the rights of students, it is also very simple, rough. For example, "education law" article 42 regulation "is not satisfied with the school to give punishment to the relevant authorities to lodge a complaint, for schools, teachers' personal rights infringement, property rights and other legitimate rights and interests, to lodge a complaint or filed a lawsuit according to law"; But only the higher education law "the legitimate rights and interests of 
students of institutions of higher learning are protected by law". "Common colleges and universities student management stipulation" the 64th regulation: "handling of students' conclusion to meet himself, allowed himself argued complaints and to disagree, to my appeal, the school has the responsibility to review". On the other hand, each on its own formulates regulations of student management in colleges and universities in the relevant rights relief program regulations, there is also a great loss. Students at Tsinghua University and Peking University and so on hundred universities disciplinary punishment regulations, we can find that in disciplinary offence to the student disciplinary regulations, relevant provisions relating to aspects of punishment to the school tend to be more detailed. Such as: how to make, the conditions of implementing decisions all have detailed provisions, such as the relief but involves students should enjoy rights, defend rights (told) had dulled, or no regulation. Although there are some regulations of this university students' right to a hearing and the right to defend oneself, or "is not satisfied with the punishment decision can students in the three days after the notified authorities put forward written application" and other rules, but for students should be how to exercise these rights, is often a lack of complete procedural rules, which gives the students a certain degree of relief rights (hearing, the right to defend), but not told how they should exercise their rights. The effect of these rights is compromised. Is an important cause of this phenomenon: the hearing system is the university student management has been gradually into the line of sight of people, in recent years and many laws and regulations and rules of the school is many years ago of the old rules. [9]

In Britain, the university student management program embodies the ancient natural justice principle of requirement, and thus set a fair hearing procedure on the basis of principle. For example, in some cases, the court demands of academic institutions must abide by the principle of natural justice, is provided by the students of disciplinary hearing, the solid content of academic judgment although court cannot intervene, but at least the requirements of the process is necessary. In many cases, the jurisdiction of the court may, because of the University of the Inspectors Abuse of power, in violation of the principle of natural justice, revoke the decision; Students failed the exam for expelled or deviant behavior, before they have a right to fair treatment, by hearing.

At present, our country should perfect the relevant education laws and regulations, clear procedural rules in the management of the teachers and students also need a longer process, manufactures could do. But, it is worth rejoicing, on perfecting relevant education laws and regulations has caused the attention of the national education department, began in March 2004 in education modification work has been made clear that the student rights protection and relief channels should be clear and perfect further. On March 29, 2005, the ministry of education has issued a new "common colleges and universities student management regulations" and "common colleges and universities student code of conduct", "the two new versions of the regulations on September 1, 2005 formally implemented. The new version of" the common colleges and universities student management regulations, "to safeguard the legitimate rights and interests of students, the new" students' rights and obligations "chapter, schools and students both sides of the aircraft; processing requirements of students drop out of school, student should have the principal findings from a study of the meeting; and identify the student to leave school or disciplinary statement and plea and the right of appeal, the school has clear guarantee program. On this basis, we look forward to the administrative hearing system in colleges and universities to establish as soon as possible.

\section{The Rules of Hearing Procedure Is Not Sound}

The lack of right remedy procedural rules is the most critical problem of the regulations in colleges and universities in our country. The program is the basic safeguard rights effectiveness. At present, although some laws and regulations and school's regulations for teachers and students' rights and interests are harmed can lodge a complaint to make the rules, but not make further provisions to appeal to deal with the introduction of hearing procedure, thus leading to the actual effect of the rules of relief right has been questioned. As prescribed in article 39 of the "teacher", "teachers for schools or other institutions of education infringe upon their legitimate rights and interests, or the handling of schools or other institutions of education make a disaffected, can appeal to the administrative department for education, the education administrative department shall, within 30 days after receiving a complaint, deal with". This provision does not include right remedy main body participation mechanism. And although there have been in the university internal management rules applicable hearing procedure within certain limits, but hearing system program rules often lack enough normative, regulation between schools are not unified. Such as the Beijing haidian district on the implementation of "disciplinary hearing students" work notice "provisions on hearing more meticulous, in the detailed rules for the file of the hearing personnel qualification and determine the preliminary opinion of, notify the school, students complaint, student delegation to discuss, appeal to parents, school boards to form the final decision after discussion of the four stages, but the most key elements missed hearing procedure: each work, who will chair the detailed instructions for how to do, time arrangement, which leads to the lack of operability.

\section{REFERENCES}

[1]. Xie Pi-Chun, emergency: "administrative law", the Chinese people's university press, 2002, pp.225.

[2]. Yang Huiji: "hearing procedure theory and practice", Shanghai people's publishing house, 1997, pp. 10.

[3]. Xu Bing, Pan Shijiang, Li Xiangru, Jeddah Beads, Chen Duan Hong, Li Danru translation, William wade: "administrative law", the encyclopedia of China publishing house, 1997. 
[4]. Wang Junyi, Bernard Schwartz: journal of the American legal history, law press, 2007.

[5]. Zhang Hui-Hua, "On the Hearing and Remedy Approaches of China's University Management", Advances in Economics Business and Management Research (AEBMR2015), vol. 6, Aug. 2015, pp622.

[6]. Ma Huaide, the rise of China's administrative law, Peking University press, 2005, pp. 409.

[7]. Zhang Hui-Hua, "Theory of Construction of Chinese Administrative Hearing System in Colleges and Universities", Advances in
Economics Business and Management Research (AEBMR2015), vol. 6, Aug. 2015, pp. 614.

[8]. http://www.huaxia.com/qtzmd/jrhn/hnxw/2016/01/4703707.html.

[9]. Zhang Hui-Hua, "On the Necessity and Feasibility of Hearings in Management System of Chinese Colleges and Universities", International Conference on Management Science and Management Innovation (MSMI2014), vol.1, June, 2014, pp.682. 